\title{
Energy balance of food in a detrito-bryophagous groundhopper (Orthoptera: Tetrigidae)
}

\author{
Kateřina Kuřavová ${ }^{1}$, Jan Šipoš ${ }^{2}$, Petr Kočárek ${ }^{\text {Corresp. } 1}$ \\ ${ }^{1}$ Department of Biology and Ecology, University of Ostrava, Ostrava, Czech Republic \\ 2 Department of Zoology, Fisheries, Hydrobiology and Apiculture, Mendel University in Brno, Brno, Czech Republic \\ Corresponding Author: Petr Kočárek \\ Email address: petr.kocarek@osu.cz
}

Detritus (decaying organic matter) and phyllodes of mosses are two main components in the diet of groundhoppers (Orthoptera: Tetrigidae). We studied the energy balance of consumed food under laboratory conditions in the detrito-bryophagous groundhopper, Tetrix subulata (Linnaeus, 1758). The results indicated that the energy food budget of this detrito-bryophagous groundhopper was comparable to those of small herbivorous grasshoppers (Acrididae: Gomphocerinae, Melanoplinae), which have a similar energy food budget of approximately 800-1100 J/g. T. subulata consumed four times more detritus than mosses, although both components provided similar amounts of energy (ca. 15-16 $\mathrm{kJ} / \mathrm{g}$ ). However, in contrast with detritus, moss fragments passed through the digestive tract without a distinct change in their mass or a loss in their energy value. We assume that moss may cause the longer retention of semifluid mass of partly digested food in the alimentary tract; hence, the digestion and efficiency of nutrient absorption from detritus could be more effective. 
1 Energy balance of food in a detrito-bryophagous groundhopper (Orthoptera: Tetrigidae)

2

3 Kateřina Kuřavová ${ }^{1}$, Jan Šipoš ${ }^{2}$, Petr Kočárek ${ }^{1}$

$4{ }^{1}$ Department of Biology and Ecology, Faculty of Science, University of Ostrava, Chittussiho 10, 5 CZ 71000 Slezská Ostrava, Czech Republic.

6 2Department of Zoology, Fisheries, Hydrobiology and Apiculture, Mendel University in Brno, 7 Brno, Czech Republic.

8

9 Corresponding Author:

10 Petr Kočárek ${ }^{1}$

$11{ }^{1}$ Department of Biology and Ecology, Faculty of Science, University of Ostrava, Chittussiho 10, 12 CZ 71000 Slezská Ostrava, Czech Republic.

13 Email address: petr.kocarek@osu.cz

14 


\section{Abstract}

16 Detritus (decaying organic matter) and phyllodes of mosses are two main components in the diet

17 of groundhoppers (Orthoptera: Tetrigidae). We studied the energy balance of consumed food

18 under laboratory conditions in the detrito-bryophagous groundhopper, Tetrix subulata (Linnaeus,

19 1758). The results indicated that the energy food budget of this detrito-bryophagous

20 groundhopper was comparable to those of small herbivorous grasshoppers (Acrididae:

21 Gomphocerinae, Melanoplinae), which have a similar energy food budget of approximately 800-

$221100 \mathrm{~J} / \mathrm{g}$. T. subulata consumed four times more detritus than mosses, although both components

23 provided similar amounts of energy (ca. 15-16 kJ/g). However, in contrast with detritus, moss

24 fragments passed through the digestive tract without a distinct change in their mass or a loss in

25 their energy value. We assume that moss may cause the longer retention of semifluid mass of 26 partly digested food in the alimentary tract; hence, the digestion and efficiency of nutrient 27 absorption from detritus could be more effective.

30 Key words Calorimetry, energy budget, foraging strategy, dietary preferences, herbivory. 


\section{INTRODUCTION}

Optimal foraging theory predicts that a foraging organism will maximize its fitness by maximizing its net energy intake per unit of time (Stephens \& Krebs, 1986)and will more often choose the available food components that yield the most calories for the effort it takes to locate, catch, or consume them (Stephens \& Krebs, 1986). This theory explains natural foraging selection through quantitative models. Energy budgets are based upon the equation Ingestion = $($ Assimilation $=$ Production + Respiration $)+$ Egestion $($ White \& Watson, 1972; McEvoy, 1985).

Herbivores usually consume nutritionally rich food sources, and they select combinations of food that vary in quality and quantity (Bernays, 1985; Bernays \& Simpson, 1990; Simpson \& Raubenheimer, 2012). In general, little is known about the energy balances or associated food strategies of insects (especially in detritivores or bryovores).

Groundhoppers (Orthoptera: Tetrigidae) have a conservative feeding strategy of detritobryophagy (the consumption of detritus and lower plants) (e.g. Verdcourt, 1947; Paranjape \& Bhalerao, 1985; Hochkirch et al., 2000; Kočárek et al., 2008; Karpestam \& Forsman, 2011; Kuřavová \& Kočárek, 2015) that is conditioned by phylogenetic dietary conservatism (Kuřavová et al., 2017a). The proportions of consumed food components are very similar across different subfamilies and across species that occupy different habitats and live in different geographic regions, with detritus (soil particles with unidentified decomposed organic matter) comprising $80-90 \%$ of the diet, moss tissues comprising $15-12 \%$ of the diet, and residual matter (pollen grains, fungal hyphae, algae, mineral particles, and the body parts of various invertebrates) comprising 1-5\% of the diet (Kuřavová et al., 2017a). Detritus is digested with higher efficiency (digestibility 91\%) than moss tissue, which has a digestibility of approximately $60 \%$ (Kuřavová 
54 \& Kočárek, 2017). To date, the energy balance of the groundhopper foraging feeding strategy is 55 unknown.

56

57

58

59

60

61

62

63

64

65

66

67

68

69

70

71

72

73

74

75

76

In this study, we focus on the following question: Is there any difference in the caloric values of the two dominant components of the groundhopper diet, and if so, does the selective utilization of these components correspond with the optimal foraging theory?

\section{METHODS}

Insect. Tetrix subulata is one of the most widespread groundhopper species in Europe (Holst, 1986). The body length of adults ranges from 10 to $14 \mathrm{~mm}$, and females are usually larger than males (Steenman et al., 2013, 2015; Lehmann et al., 2018). This species is active from March to the end of October in Central Europe (Holst, 1986; Kočárek et al., 2005), when nymphs hatch in summer (August), molt to adulthood in autumn, hibernate and reproduce in spring. The adult season is split into the autumn dispersal-related cohort (Lehmann et al., 2018) and the reproducing spring cohort (Steenman et al.,2015). The groundhopper usually prefers damp places, and it is often found near rivers in moist habitats (Baur et al., 2006). The diet of $T$. subulata includes detritus, mosses (e.g., genera Brachythecium, Bryum, Calliergonella), algae, and small amounts of other substrates (Ingrisch \& Köhler, 1998; Hochkirch et al., 2000; Kuřavová \& Kočárek, 2017).

Experimental design. Randomly selected adults of T. subulata (brachypronotal or macroptonotal, brachypronotal dominated in a 4:1 ratio) of the spring cohort after the hibernation were collected by sweeping in flooded depressions of meadow near the city of Ostrava, Czech Republic (49 $\left.51^{\prime} 40.4^{\prime \prime} \mathrm{N}, 18^{\circ} 11^{\prime} 19.5^{\prime \prime} \mathrm{E}\right)$, from 20 Apr to 28 May 2014. Specimens were transported in plastic boxes to the laboratory at the Department of Biology and Ecology, 
77 University of Ostrava. The energy balance of food was evaluated using the gravimetric ingestion method (Waldbauer, 1968; Kogan \& Para, 1981; McEvoy, 1985). This experiment consists of the following parts: the acclimatization of specimens, food deprivation, feeding and calorimetric analysis of samples.

Acclimatization. Specimens were acclimated in eight insectaria in laboratory conditions for three days (approximately 40 individuals per insectarium $(30 \times 15 \times 20 \mathrm{~cm})$ with a sex ratio of $1: 1)$. The insectaria were ventilated by covering their tops with textile membranes with $1 \times 1$ $\mathrm{mm}$ pores. Each insectarium contained a soil depth of $7 \mathrm{~cm}$ (a mixture of detritus fragments), planted mosses, including Brachythecium rutabulum (Hedw.) B.S.G. and Calliergonella cuspidata (Hedw.) Loeske as well as the grass (Festuca spp.). The upper layer of the substrate was covered with $70 \%$ bare soil, $20 \%$ mosses and $10 \%$ grass. The soil layer in the insectaria was kept slightly wetted with water. Both substrate and all plants used in insectaria were collected from the same locality as the specimens.

Food deprivation. The acclimated specimens were placed in plastic boxes $(25 \times 25 \times 25$ $\mathrm{cm})$ to empty their digestive tracts. The boxes had double bottoms. The inner bottom was composed of a perforated textile membrane with $1 \times 1 \mathrm{~mm}$ pores, which allowed feces to pass through. Each box contained a wet inert fabric (cotton wool) to provide drinking water. Food deprivation lasted $24 \mathrm{~h}$ for each specimen. The sufficiency of food deprivation (i.e., the rate of food passage through the digestive tract) was tested experimentally in a microclimate chamber (Snijders Imago 500, Tilburg, The Netherlands) under laboratory conditions (temperature $25^{\circ} \mathrm{C}$, humidity $80 \%$, photoperiod $12 \mathrm{~h}$ light and $12 \mathrm{~h}$ dark). The mean rate of food passage through the alimentary tract was approximately $5 \mathrm{~h}$ for detritus and approximately $7 \mathrm{~h}$ for the moss $C$. cuspidata. The last fecal pellet was recorded $22 \mathrm{~h}$ after the last consumption of detritus and moss. 

particles and decaying organic matter), "feeding group with Calliergonella cuspidata" (only diet was adjusted before it was served, the detritus and mosses were air-dried to a constant of ash in the organic matrix were analyzed by the adiabatic calorimeter IKA C4000 (Staufen,

115 Germany) (Table 1). Before serving, the detritus and the mosses were again wetted (moss was submerged in water for $20 \mathrm{~min}$, and detritus was wetted with water to achieve a $2: 1$ ratio). Wet phyllodes of mosses and wet detritus were placed separately into boxes. All boxes, specimens and served food were controlled twice a day (in 12-h periods). Defecated feces fell individually down into a collection container (the lower of the container bottoms). The feces were collected were frozen at $-18^{\circ} \mathrm{C}$ (Beko freezer, CN 237231, Gaesti, Romania). 
Calorimetric analysis. The collected feces were analyzed with an adiabatic calorimeter

123 (IKA C4000, Staufen, Germany), identical to the method used by Hadley and Bliss (1964),

124 White (1978) and Köhler et al. (1987). Benzoic acid $\left(\mathrm{C}_{6} \mathrm{H}_{5} \mathrm{COOH}, 26 \mathrm{~kJ} / \mathrm{g}\right)$ was used for

125 calibration. The calorific value of a sample was expressed as calories per gram of ash-free

126 sample. The ash residues were recorded for all samples.

A total of 240 individuals (20 males and 20 females in each feeding group with two replications) were used in this experiment. Acclimation, food deprivation, feeding, and fecal collection were conducted in a climate chamber (Snijders Imago 500, Tiburg, The Netherlands) with temperature held at $25^{\circ} \mathrm{C}$ and humidity at $70 \%$ during the day $(12 \mathrm{~h}$ of light $)$ and $23^{\circ} \mathrm{C}$ and $80 \%$, respectively, during the night (12 h of dark). These conditions were constant over the experiment.

Data analyses. The experiment was evaluated using the gravimetric method that relies on ingestion and egestion (White \& Watson, 1972), where Ingestion = Assimilation + Egestion . The assimilated energy was determined by the difference between the initial (calorific value of ingested food component) and the final (calorific value of egested feces) dry matter using the 137 following equations:

individuals using the following formula:

$$
C V_{\text {diet }}=C V_{\text {digested }}-C V_{\text {feces }}, \quad[\mathrm{J} / \mathrm{g}]
$$

and $i$ is the type of food (detritus, moss species).

using the following formula, and it is the calorific value that the specimen gains from food:

$$
R C V_{\text {diet } i}=C V_{\text {diet }}-A D_{\text {diet } i}, \quad[\mathrm{~J}]
$$


145 where $A D_{\text {diet }}$ is the approximate digestibility of food and $i$ is the type of food (detritus, moss).

146 The approximate digestibility of food components in the groundhopper T. subulata was

147 calculated by Kuřavová \& Kočárek (2017) according to the following formula:

$148 \quad A D=(W C F-W F / W C F) \times 100$,

149 where $W C F$ is the weight (mg) of the consumed food and $W F$ is the weight (mg) of the feces.

$150 \quad$ The energy food budget $\left(E_{f b}\right)$ was calculated for each specimen using the following

151 formula:

152

$$
E_{f b i}=R C V_{\text {diet } i} \times 4.187
$$

153

where 4.187 is the conversion factor used to convert the calorific value to joules, and $i$ is the type

of food (detritus, moss species).

The overall experimental design was a 2 x 3 factorial design ( 2 sexes and 3 levels of food source) interaction were entered into the models as fixed effects, and replicates were entered as random effects. For data analysis, we used repeated-measures nonparametric ANOVA (ligned rank transformation ANOVA). It is a robust statistical tool for the analysis of multiple factorial designs with non-normal residuals. Before using ANOVA itself the data were transformed by the “art” function (ARTool package) (Wobbrock et al. 2011). This function first aligns the data for each effect (main or interaction) and then assigns averaged ranks (Mansouri et al. 1998). The post hoc comparison of the main effect for food source was conducted by the "emmeans" package with Bonferroni corrected p-values (Russell 2019). All analyses were performed using

165 the statistical software R (Ver. 3.1.3, Vienna, Austria) (R Development Core Team, 2015). The 166 level of probability was considered significant at a P-value $<0.05$. 
169 Females weighed an average of $71.49 \pm 8.83 \mathrm{mg}$ and were therefore nearly twice as heavy as

170 males $(32.70 \pm 3.88 \mathrm{mg})(\mathrm{df}=1, F=686.70, p<0.01$, Table 2$)$. The weights of males and

171 females did not differ significantly among feeding groups consuming different types of food

$172\left(F_{2,3.9}=4.46, p=0.096\right.$, Table 2$)$. The fecal weights significantly differed between males and

173 females $\left(F_{1,6.2}=19.08, p<0.01\right)$, and females had approximately $13.32 \pm 0.53 \mathrm{mg}(\mathrm{ca} 50 \%)$

174 heavier feces than males.

175 The calorific values of served food differed significantly from each other $\left(F_{2,4}=7, p=\right.$ 176 0.049, Table 1). The Tukey HSD test confirmed that the calorific values of detritus and 177 Brachythecium rutabulum, and Calliergonella cuspidata mosses were similar, but the calorific 178 values of B. rutabulum moss were slightly different from those of C. cuspidata moss (Table 3). 179 Ash matter significantly differed among the types of food served $\left(F_{2,4}=11.46, p=0.022\right.$, Table 180 1). Detritus contained more ash matter than both mosses. The Tukey HSD test confirmed that the 181 ash matter slightly differed among the types of served food (Table 3) but not between the two 182 served mosses. The energy food budgets in individual feeding groups and this parameter differed 183 significantly between the type of served food $\left(F_{2,8}=18.51, p<0.001\right)$ and between males and 184 females $\left(F_{1,4}=37.39, p<0.01\right)$ (Table 4$)$.

The energy food budgets of $T$. subulata are comparable to the energy food budgets of small herbivorous grasshoppers from the family Acrididae (Acridinae: Chorthippus biguttulus, Gomphocerippus rufus, and Pseudochorthippus parallelus; Melanoplinae: Melanoplus femurrubrum, and M. sanguinipes), with similar energy food budgets of approximately 800189 $1100 \mathrm{~J} / \mathrm{g}$ (Fig. 1).

The groundhopper T. subulata consumes four times more detritus than mosses, although 191 both food components provide a similar amount of energy (Table 1). Females obtain more 
192 energy from food than males. Feces contain more moss fragments than other waste products in a 193 proportion of 4.5:1 (Table 4). Assimilated energy of served food in males and females was 194 significantly different $\left(\mathrm{F}_{2,8}=71.09, \mathrm{p}<0.001\right)$ in that males obtain more energy from mosses than 195 females, but females obtain more energy from detritus (Fig. 2). The Tukey HSD test confirmed 196 that the energy budgets of specimens differed between the detritus and moss feeding groups

197 (Table 3, Fig. 3) but not between the two moss feeding groups.

\section{DISCUSSION}

Based on the gravimetric method that relies on ingestion, we confirmed that energy food budgets differ between two dominant food components in the detrito-bryophagous groundhopper Tetrix subulata. Decaying organic matter (detritus) is assimilated more effectively, has higher digestibility, and provides more energy than moss tissues (Fig. 3).

The dietary preferences of groundhoppers are relatively well known; the main component of their diet is detritus, and minor components include a mixture of moss species (Kočárek et al., 2008; Kuřavová \& Kočárek 2015; Kuřavová et al., 2017). Groundhoppers frequently consume moss species that are dominant at each locality, but some species-specific preferences in moss consumption have been observed (Kuřavová et al., 2017b). Both basic components of groundhopper diets (detritus and moss) differ in chemical composition (Frankland, 1974; Rice, 1982; Enriquez et al., 1993; Asakawa, 1995, 2007; Maksimova et al., 2013). Conducted analyses

211 show that detritus has a higher percentage of silicon, while moss is richer in other elements 212 (particularly carbon, phosphor, Table 1). The results of our elemental analysis of mosses are

213 comparable with the ranges of basic elements found in other bryophytes (Maksimova et al., 214 2013). In terms of energy food richness, both food components were balanced (i.e., provided 
215 approximately $15-16 \mathrm{~kJ} / \mathrm{g}$ ), but detritus seemed to contain more easily digestible compounds 216 than moss (Kuřavová et al., 2017).

Insect energetics, qualitative nutritional requirements of insects, consumption rates and energy balances in insects have all been studied (see Wiegert \& Petersen 1983, and McEvoy 1985 for reviews), and the energy budgets have also been analyzed in some herbivorous grasshoppers (e.g. Nagy, 1952; Duke \& Crossley 1975; White 1978; Belovsky, 1986; Köhler et al., 1987). The contents of the alimentary tracts often included a mixture of grass species in the studied grasshoppers, e.g., Lolium perenne L., Poa pratensis L., Festuca rubra L. and Dactylis glomerata L. We analyzed the energy food budget of a detrito-bryophagous groundhopper using the gravimetric method proposed in the abovementioned studies (Belovsky, 1986; Köhler et al., 1987). We can compare the energy food budgets across used Orthoptera species, and the results indicated that the energy food budgets are comparable in small herbivorous grasshoppers of 227 similar weight (see Fig. 1).

The theory of optimal foraging strategy explains multidimensional feeding selection in various animals (Stephens \& Krebs, 1986; Raubenheimer \& Simpson, 1993; Sinervo et al., 1997), whereas herbivorous insects require food with a mixture of nutrients to sustain growth, development and reproduction, and they must regulate their nutrient intake (Behmer, 2009). Consumers always try to obtain an optimal balance of food components over time (Berner et al., 2005; Simpson, 1990; Simpson et al., 2002). We found that T. subulata consumes significantly greater amounts of detritus than mosses, although both food components provide a similar amount of energy (ca. 15-16 kJ/g) (Fig. 3). This variance has important implications for assimilation and energy yield. 

mosses in proportion 11.5:1 (Fig. 3), whereas moss tissues pass through the alimentary tract without providing significant energy benefits for specimens. During our previous studies we

240 tested two working hypotheses: 1) moss tissues are a significant source of water in dry 241 season/day periods, and 2) groundhoppers might consume mosses to obtain cryoprotectants 242 (Cornelissen et al., 2007) in the case of an autumn cohort. Kuřavová et al. (2017b) studied 243 whether groundhoppers consumed mosses to obtain water by comparing of the food composition 244 at two sites that differed considerably in water availability (humid vs. dry microhabitat). The 245 results suggest that the studied species $T$. tenuicornis and $T$. ceperoi predominantly consumed the available mosses, i.e., the most frequently consumed mosses were the dominant species at 247 each site. Regardless, some desiccation-tolerant (and concurrently nutritionally rich) moss species seemed to be more consumed at the dry versus the humid site. The second hypothesis was rejected based on the finding that groundhoppers consumed more mosses in spring and summer than in autumn before hibernation (Kuřavová \& Kočárek 2015).

The most likely hypothesis, which could explain the regular consumption of moss, seems to be that moss fragments facilitate a longer retention time of chyme in the alimentary tract, improving digestion and efficiency of nutrient absorption. Therefore, moss tissues may perform the same function as dietary fiber in omnivorous vertebrates (Truswell, 1993). Evidence for this claim is that the passage of detritus through the alimentary tract is faster than that of moss (on average $5 \mathrm{~h}$ vs. $7 \mathrm{~h}$ ). The rate of the passage of different foods through the alimentary tract is the

257 subject of ongoing experiments (Kuřavová et al., in prep.). Groundhoppers are a 258 phylogenetically ancient group of orthopterans that exhibit conservative feeding strategy 259 (Kuřavová et al., 2017a), which could be associated with the absence of an enzymatic apparatus 
260 necessary for the digestion of some nutrients (esp. polysaccharides) of vascular plants. Basic

261 nutrients (saccharides, proteins) are accessible in partially digested form in detritus

262 (oligosaccharides, oligopeptides); thus, they are easier for groundhoppers to digest and can

263 compensate for the absence (or low effectiveness) of their own specific enzymes. Kuřavová et al.

264 (2014) found a high level of mechanical wearing of mandibles as a result of feeding in $T$.

265 tenuicornis. Less sclerotized and easily abradable cuticle may be one of the the reasons why

266 groundhoppers avoid feeding on silica-rich higher plants.

267 In conclusion, we evaluated the energy balance of food in a detrito-bryophagous

268 groundhopper under laboratory conditions. Detritus is consumed and digested more efficiently

269 and is the most significant energy source in the groundhopper diet. Moss tissues pass through the

270 digestive tract in almost unchanged form; therefore, we conclude that mosses are unimportant

271 sources of energy for groundhoppers. Moss fragments may cause the longer retention of chyme

272 in the alimentary tract; hence, the digestion and efficiency of nutrient absorption could be more

273 effective.

274

\section{ACKNOWLEDGMENTS}

276 The authors thank chemist Boleslav Taraba (CZE) and technologist Jiř́ Fiedor (CZE) for 277 providing laboratory equipment during the experiment. We thank Carlos Sperber, Axel 278 Hochkirch and a third anonymous reviewer for very helpful comments that improved the 279 manuscript.

\section{REFERENCES}

Asakawa Y. 1995. Chemical constituents of the bryophytes. Springer, Vienna. 
283 Asakawa Y. 2007. Biologically active compounds from bryophytes. Pure and Applied Chemistry

284 79: 557-580.

285 Baur B, Baur H, Roesti D. 2006. Die Heuschrecken der Schweiz. Haupt, Bern.

286 Behmer ST. 2009. Insect herbivore nutrient regulation. Annual Review of Entomology 54: 165287187.

288 Belovsky GE. 1986. Optimal foraging and community structure: implications for a guild of 289 generalist grassland herbivores. Oecologia 70: 35-52.

290 Bernays EA. 1985. Regulation of feeding behavior. Comparative insect physiology, biochemistry 291 and pharmacology 4: 1-32.

292 Bernays EA, Simpson SJ. 1990. Nutrition. In: Chapman RF, Joern A, ed. Biology of 293 grasshoppers. New York: John Wiley \& Sons, 105-128.

294 Berner D, Blanckenhorn WU, Körner C. 2005. Grasshoppers cope with low host plant quality by 295 compensatory feeding and food selection: N limitation challenged. Oikos 111: 525-533.

296 Cornelissen JHC, Lang, SI, Soudzilovskaia NA, During HJ. 2007. Comparative cryptogam 297 ecology: a review of bryophyte and lichen traits that drive biogeochemistry. Annals of Botany 298 99: 987-1001.

299 Duke KM, Crossley DA. 1975. Population energetics and ecology of the rock grasshopper, 300 Trimerotropis saxatilis. Ecology 56: 1106-1117.

301 Enríquez SCMD, Duarte CM, Sand-Jensen KAJ. 1993. Patterns in decomposition rates among 302 photosynthetic organisms: the importance of detritus C: N: P content. Oecologia 94: 457-471. 
303 Frankland JC. 1974. Decomposition of lower plants. Biology of plant litter decomposition 1: 330436.

305 Frens KM. 2010. Effects of food type and patch location on foraging: a field test of optimal 306 foraging predictions. Thesis, University of Michigan.

307 Hadley EB, Bliss LC. 1964. Energy relationships of alpine plants of Mt. Washington, New 308 Hampshire. Ecological Monographs 34: 332-357.

309 Hochkirch A, Gröning J, Loos T, Metzing C, Reichelt M. 2000. Specialized diet and feeding 310 habits as key factors for the habitat requirements of the grasshopper species Tetrix subulata 311 (Orthoptera: Tetrigidae). Entomologia Generalis 25: 039-051.

312 Holst KT. 1986. The Saltatoria of Northern Europe (Bushcrickets, crickets and grasshoppers. 313 Scandinavian Science Press, Leiden.

314 Ingrisch S, Kohler G. 1998. Die Heuschrecken Mitteleuropas. Westarp Wissenschaften, 315 Magdeburg.

316 Karpestam E, Forsman A. 2011. Dietary differences among colour morphs of pygmy 317 grasshoppers revealed by behavioural experiments and stable isotopes. Evolutionary Ecology 318 Research 13: 461-477.

319 Kočárek P, Holuša J, Vidlička L. 2005. Blattaria, Mantodea, Orthoptera \& Dermaptera of the 320 Czech and Slovak Republics. Kabourek, Zlín.

321 Kočárek P, Grucmanová Š, Filipcová Z, Bradová L, Plášek V, Holuša J. 2008. Bryophagy in the 322 grasshopper Tetrix ceperoi (Orthoptera: Tetrigidae): analysis of alimentary tract contents. In:

323 Kočárek P, Plášek V, Malachová K, Cimalová Š, eds. Environmental changes and biological 
assessment IV. Scripta Facultatis Rerum Naturalium Universitatis Ostraviensis. Ostrava:

325 University of Ostrava, 348-352.

326 Kogan M, Parra JR. 1981. Techniques and applications of measurements of consumption and

327 utilization of food by phytophagous insects. In: Bhaskaran G, Friedman S, Rodriguez JG, eds.

328 Current topics in insect endocrinology and nutrition. USA: Springer, 337-352.

329 Köhler G, Brodhun HP, Schäller G. 1987. Ecological energetics of central European 330 grasshoppers (Orthoptera: Acrididae). Oecologia 74: 112-121.

331 Kuřavová K, Hajduková L, Kočárek P. 2014. Age-related mandible abrasion in the

332 groundhopper Tetrix tenuicornis (Tetrigidae, Orthoptera). Arthropod Structure \& Development 333 43: 187-192.

334 Kuřavová K, Kočárek P. 2015. Seasonal variation in the diet of Tetrix tenuicornis (Orthoptera:

335 Tetrigidae). Entomological Science 18: 489-501.

336 Kuřavová K, Kočárek P. 2017. Food digestibility and consumption rate in detrito-bryophagous

337 groundhopper Tetrix subulata (Orthoptera: Tetrigidae). Biologia 72: 452-457.

338 Kuřavová K, Šipoš J, Wahab RA, Kahar RS, Kočárek P. 2017a. Feeding patterns in tropical 339 groundhoppers (Tetrigidae): a case of phylogenetic dietary conservatism in a basal group of 340 Caelifera. Zoological Journal of the Linnean Society 179: 291-302.

341 Kuřavová K, Grucmanová Š, Filipcová Z, Plášek V, Drozd P, Kočárek P. 2017b. Is feeding on 342 mosses by groundhoppers in the genus Tetrix (Insecta: Orthoptera) opportunistic or selective? 343 Arthropod-Plant Interactions 11: 35-43. 
344 Lehmann GUC, Marco HG, Lehmann AW, Gäde G. 2018. Seasonal differences in body mass

345 and circulating metabolites in a wing-dimorphic pygmy grasshoppers: implications for life.

346 Ecological entomology 43: 675-682.

347 Maksimova V, Klavina L, Bikovens O, Zicmanis A, Purmalis O. 2013. Structural

348 characterization and chemical classification of some bryophytes found in Latvia. Chemistry \&

349 Biodiversity 10: 1284-1294.

350 Mansouri H, 1998. Multifactor analysis of variance based on the aligned rank transform

351 technique. Computational Statistic \& Data Analysis 29: 177-189.

352 McEvoy PB. 1985. Balancing insect energy budgets. Oecologia 66: 154-156.

353 Nagy B. 1952. Food consumption of Dociostaurus crucigerus brevicollis Eversm. and Oedipoda

354 coerulescens L. (Orth. Acrididae). Acta Biologica Hungarica 3: 41-52.

355 Paranjape SY, Bhalerao AM. 1985. Bioecological observations on a pigmy locust, Potua 356 sabulosa Hancock (Tetrigidae: Orthoptera). Psyche 92: 331-336.

357 Raubenheimer D, Simpson SJ. 1993. The geometry of compensatory feeding in the locust. 358 Animal Behaviour 45: 953-964.

359 R Core Team. 2015. R: A Language and Environment for Statistical Computing, Version 3.3.0.

360 R Foundation for Statistical Computing, Vienna. URL: https://www.R-project.org.

361 Rice DL. 1982. The detritus nitrogen problem: New observations and perspectives from organic 362 geochemistry. Marine Ecology Progress Series 9: 153-162.

363 Russell L. 2019. emmeans: Estimated Marginal Means, aka Least-Squares Means. R package 364 version 1.4.3.01. https://CRAN.R-project.org/package=emmeans. 
365 Simpson SJ. 1990. The pattern of feeding. In: Chapman RF, Joern A, eds. Biology of 366 grasshoppers. New York: John Willey \& Sons, 73-104.

367 Simpson SJ, Raubenheimer D. 2012. The nature of nutrition. A unifying framework from animal 368 adaptation to human obesity. Princeton University Press, Princeton.

369 Simpson SJ, Raubenheimer D, Behmer ST, Whitworth A, Wright GA. 2002. A comparison of 370 nutritional regulation in solitarious- and gregarious-phase nymphs of the desert locust 371 Schistocerca gregaria. Journal of Experimental Biology 205: 121-29.

372 Sinervo B. 1997. Optimal Foraging Theory: Constraints and Cognitive Processes. In: Sinervo B, 373 ed. Behavioral Ecology. Santa Cruz: University of Carolina, 105-130.

374 Steenman A, Lehmann AW, Lehmann GUC. 2013. Life-history trade-off between macroptery 375 and reproduction in the wing- dimorphic pygmy grasshopper Tetrix subulata (Orthoptera 376 Tetrigidae). Ethology, Ecology \& Evolution 27. 93-100.

377 Steenman A, Lehmann AW, Lehmann GUC. 2015. Morphological variation and sex378 biasedfrequency of wing dimorphism in the pygmy grasshopper Tetrix subulata (Orthoptera: 379 Tetrigidae). European Journal of Entomology 110. 535-540.

380 Stephens DW, Krebs JR. 1986. Foraging theory. Princeton University Press, New Yersey.

381 Truswell AS. 1993. Dietary fiber and health. In: Simopoulos AP, ed. Nutrition and Fitness in 382 Health and Disease. Athens: Karger Publishers, 148-164.

383 Verdcourt B. 1947. A note on the food of Acridium Geoff. (Orthopt.). The Entomologist's 384 Monthly Magazine 83: 190.

385 Waldbauer GP. 1968. The consumption and utilization of food by insects. Insect Physiology 5: $386 \quad 229-288$. 
387 White EG. 1978. Energetics and consumption rates of alpine grasshoppers (Orthoptera:

388 Acrididae) in New Zealand. Oecologia 33: 17-44.

389 White EG, Watson RN. 1972. A food consumption study of three New Zealand alpine 390 grasshopper species. New Zealand Journal of Agricultural Research 15: 867-877.

391 Wiegert RG, Petersen CE. 1983. Energy transfer in insects. Annual Review of Entomology 28: $392 \quad 455-486$.

393 Wobbrock J, Findlater L, Gergle D, Higgins JJ. 2011. "The Aligned Rank Transform for 394 Nonparametric Factorial Analyses Using Only ANOVA Procedures.” In: Wobbrock J, Findlater 395 L, Gergle D, Higgins JJ, ed. Proceedings of the ACM Conference on Human Factors in 396 Computing Systems (CHI'11): 143-146. <URL: http://depts.washington.edu/aimgroup/proj/art/> 
Figure 1

Energy food budgets $(\mathrm{J} / \mathrm{g})$ in adult females of various Caelifera species determined through the gravimetric ingestion method according to Belovsky (1986), Köhler et al. (1987) and our result.

Cho-big, Chorthippus biguttulus (Linnaeus, 1758); Cir-und, Circotettix undulatus (Thomas, 1872); Dis-car, Dissosteira carolina (Linnaeus, 1758); Gom-ruf, Gomphocerippus rufus (Linnaeus, 1758); Mel-fem, Melanoplus femurrubrum (De Geer, 1773); Mel-san, Melanoplus sanguinipes (Fabricius, 1798); Pse-par, Pseudochorthippus parallelus (Zetterstedt, 1821); Tet-sub, Tetrix subulata (Linneus, 1758).

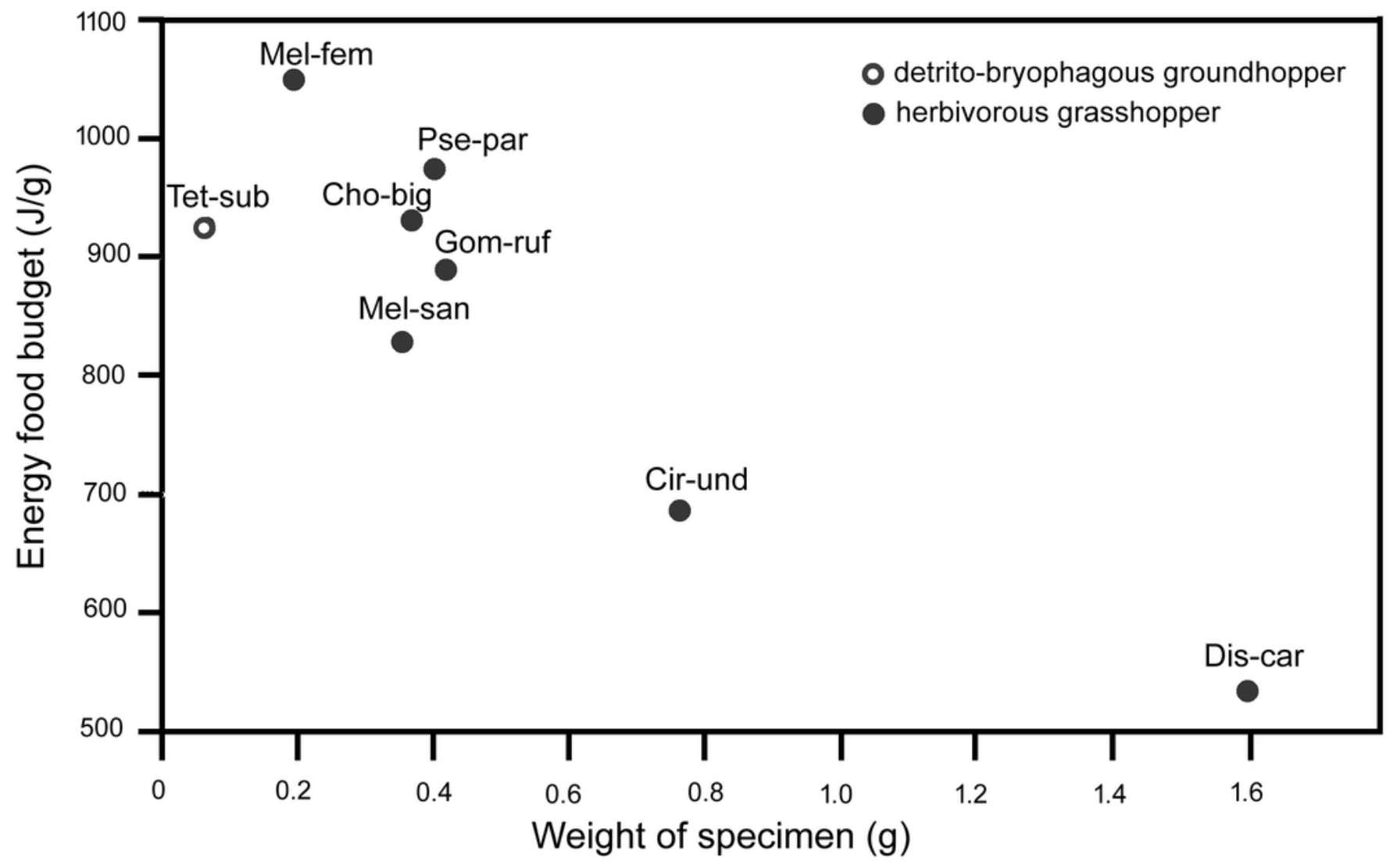


Figure 2

Assimilated energy in males and females of various feeding groups.

A. moss Brachythecium rutabulum (Bra-rut), B. moss Calliergonella cuspidata (Cal-cus), C. detritus.

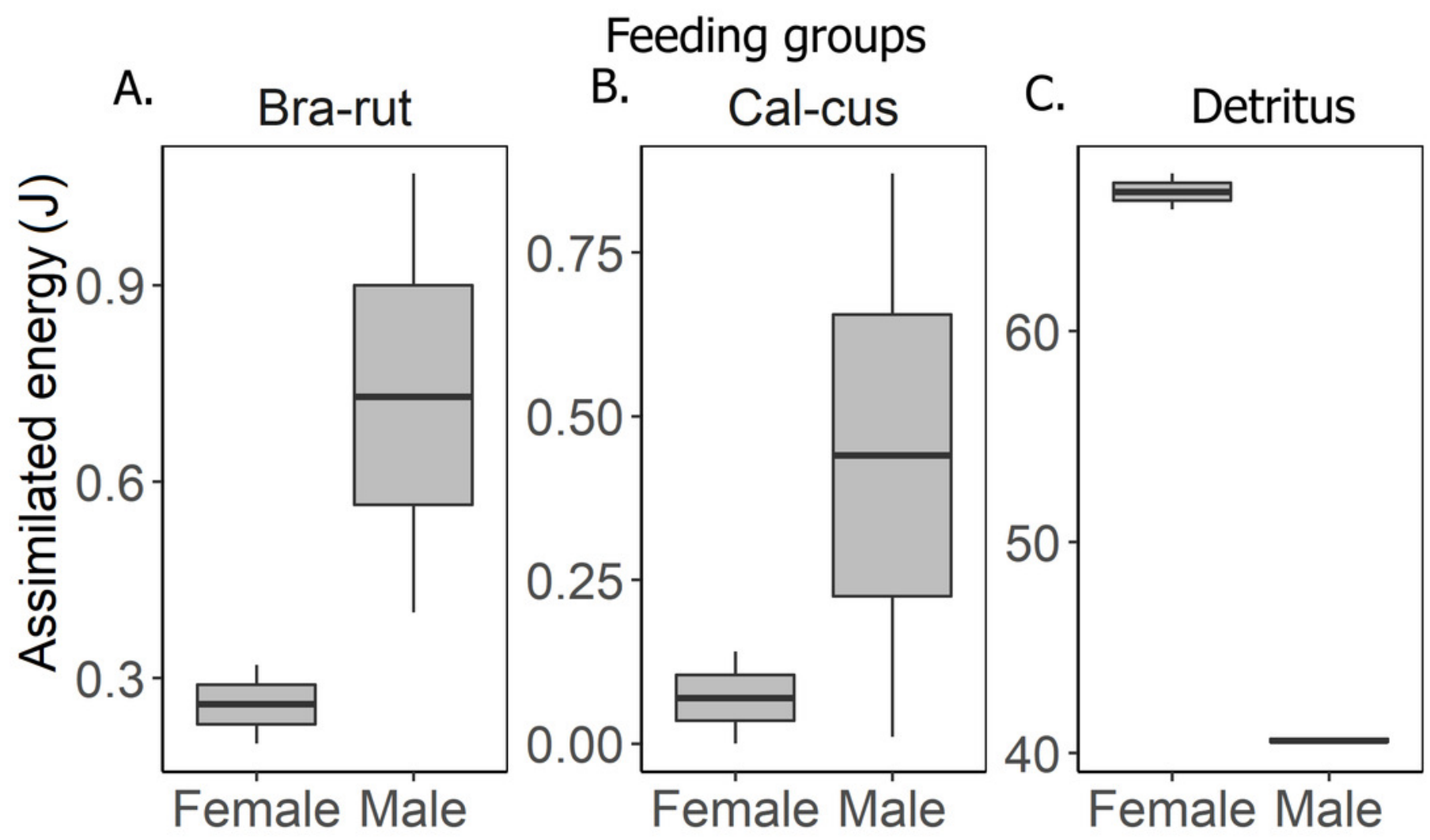




\section{Figure 3}

Food balance in detrito-bryophagous groundhopper Tetrix subulata (Orthoptera, Tetrigidae).

The food box shows the rate of detritus and moss consumption in studied groundhoppers (determined through gut content analysis according to Kuřavová et al. (2017a) and Kuřavová \& Kočárek (2017)), and the calorific values of served detritus and moss tissues measured using calorimeter method. The assimilation box shows the proportion of assimilated energy (\%) (assimilation means respiration and production of energy). The feces box shows the proportion of defecated feces (determined through the gut content analysis according to Kuřavová \& Kočárek (2017).

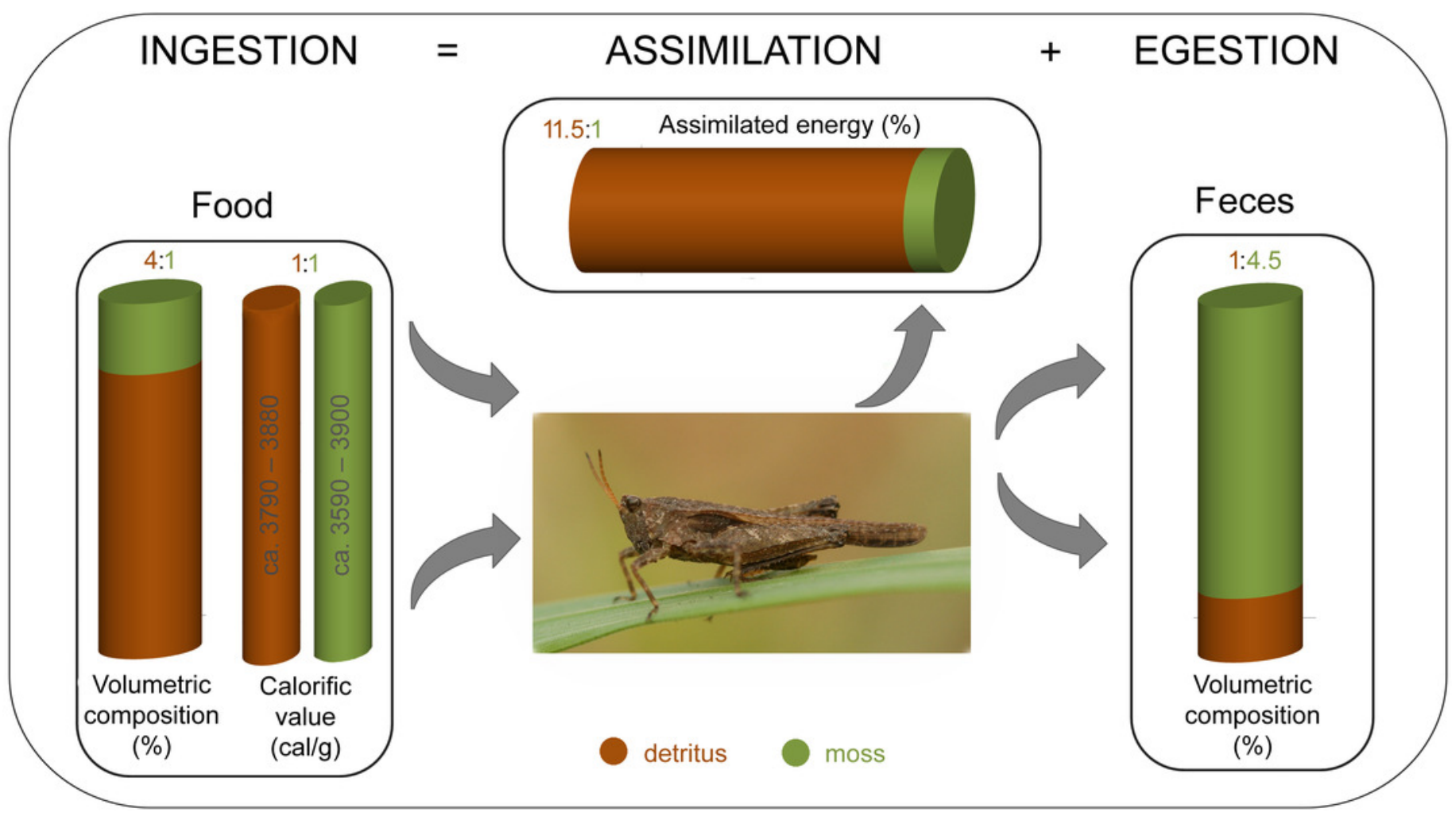




\section{Table $\mathbf{1}$ (on next page)}

The percentages of elements $(C, H, N, S, P, S)$, calorific values $\left(C_{s f}\right)$, energy values $\left(E_{s f}\right)$ and proportions of ash matter $\left(\mathrm{FA}_{\mathrm{sf}}\right)$ in foods served to Tetrix subulata at laboratory conditions. $\dagger$

Bra-rut - moss Brachythecium rutabulum, Cal-cus - moss Calliergonella cuspidata. 


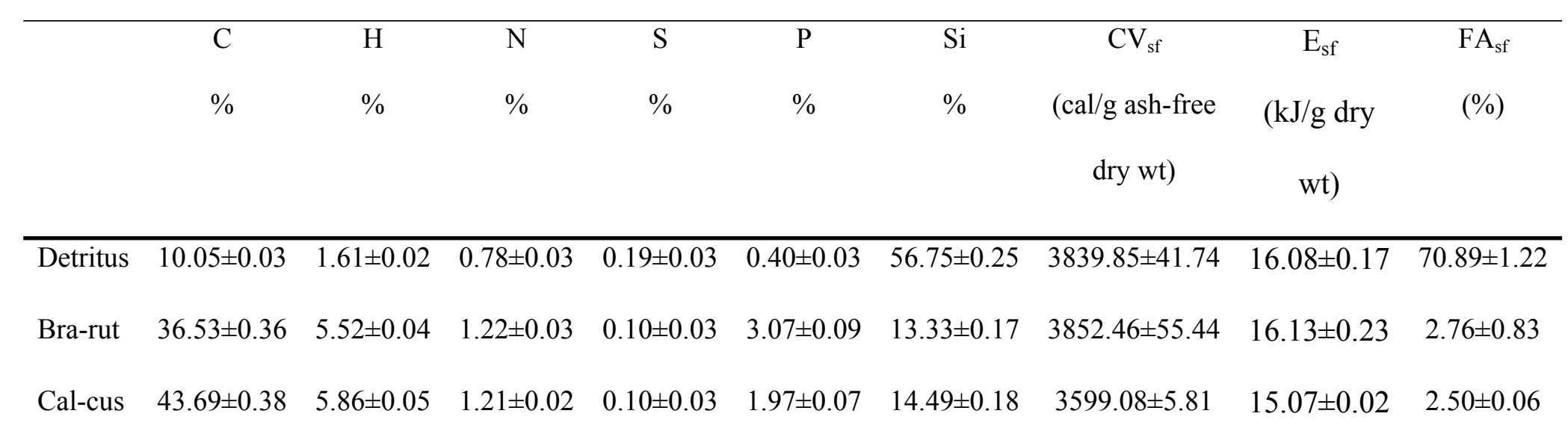

$1 \uparrow$ Three samples evaluated for each type of food. 


\section{Table 2 (on next page)}

Mean weights of males and females belonging to three different feeding groups in Tetrix subulata: detritus, moss Brachythecium rutabulum (Bra-rut) and moss Calliergonella cuspidata (Cal-cus).

The mean weights of defecated feces (in dry matter) were collected for 30 days in laboratory conditions. $\dagger$ 


\begin{tabular}{|c|c|c|c|c|c|c|}
\hline \multirow[t]{2}{*}{ Feeding group } & \multicolumn{2}{|c|}{ moss Bra-rut } & \multicolumn{2}{|c|}{ moss Cal-cus } & \multicolumn{2}{|c|}{ Detritus } \\
\hline & Male & Female & Male & Female & Male & Female \\
\hline Weight of specimens (mg) & $33.48 \pm 7.15$ & $71.58 \pm 10.58$ & $31.20 \pm 2.45$ & $71.18 \pm 7.82$ & $33.43 \pm 2.05$ & $71.70 \pm 8.10$ \\
\hline $\begin{array}{l}\text { Weight of feces } \\
\text { (mg/spec./30days) }\end{array}$ & $11.81 \pm 0.08$ & $23.43 \pm 1.63$ & $10.40 \pm 0.18$ & $23.84 \pm 0.53$ & $18.36 \pm 1.62$ & $33.26 \pm 0.43$ \\
\hline
\end{tabular}

$1 \dagger$ Each feeding group had 20 specimens with two replicates. 


\section{Table 3 (on next page)}

Tukey multiple comparisons of calorific values (value before the slash) $\left(\mathrm{CV}_{\mathrm{sf}}\right)$ and ash matter (value after the slash) $\left(\mathrm{FA}_{\mathrm{sf}}\right)$ in served food.

moss Bra-rut - Brachythecium rutabulum, moss Cal-cus - Calliergonella cuspidata, $\mathrm{E}_{\mathrm{fb}}$ - energy food budgets in feeding groups of groundhopper Tetrix subulata. The values represent the honest significant difference $(P$-value). $†$ 


\begin{tabular}{lccc}
\hline Type offood & $\mathrm{CV}_{\mathrm{sf}}$ & $\mathrm{FA}_{\mathrm{sf}}$ & $\mathrm{E}_{\mathrm{fb}}$ \\
Moss Bra-rut - Detritus & $0.71(0.77)$ & $-2.83(0.07)$ & $-3.97(<0.01)$ \\
Moss Cal-cus - Detritus & $-2.83(0.07)$ & $-3.54(0.03)$ & $-5.56(<0.01)$ \\
Moss Bra-rut - Moss Cal-cus & $3.54(0.03)$ & $0.71(0.77)$ & $1.59(0.29)$
\end{tabular}

$1 \dagger$ Each feeding group had 20 specimens with two replicates (for a total of 240 individuals). 


\section{Table 4 (on next page)}

Summary of caloric values and proportions of ash matter in assimilated food and defecated faces for males and females in Tetrix subulata.

$\mathrm{CV}_{\mathrm{df}}$ - calorific values of defecated feces per feeding group, $\mathrm{FA}_{\mathrm{df}}$ - proportions of ash matter in feces per feeding group, $\mathrm{CV}_{\mathrm{af}}$ - calorific values of assimilated food per specimen collected for 30 days, $\mathrm{RCV}_{\mathrm{af}}$ - real calorific values of assimilated food per specimen collected for 30 days, $E_{f b}$ - energy food budget $\left(E_{f b}\right)$ per specimen in feeding groups of Tetrix subulata. The feeding groups consumed three types of food: moss Brachythecium rutabulum (Bra-rut), moss Calliergonella cuspidata (Cal-cus), and detritus. The values are mean \pm standard error. $\dagger$ 


\begin{tabular}{|c|c|c|c|c|c|c|}
\hline \multirow[t]{2}{*}{ Feeding group } & \multicolumn{2}{|c|}{ moss Bra-rut } & \multicolumn{2}{|c|}{ moss Cal-cus } & \multicolumn{2}{|c|}{ Detritus } \\
\hline & Male & Female & Male & Female & Male & Female \\
\hline $\mathrm{CV}_{\mathrm{df}}(\mathrm{cal} / \mathrm{g})$ per group/30 days & $3217.21 \pm 344.38$ & $3752.62 \pm 32.48$ & $3164.86 \pm 426.33$ & $3572.08 \pm 32.75$ & $280.67 \pm 29.21$ & $862.17 \pm 3.66$ \\
\hline $\mathrm{FA}_{\mathrm{df}}(\%)$ per group/30 days & $4.71 \pm 2.09$ & $0.53 \pm 0.09$ & $6.30 \pm 1.95$ & $2.10 \pm 0.47$ & $85.86 \pm 1.45$ & $55.50 \pm 0.12$ \\
\hline $\mathrm{CV}_{\mathrm{af}}(\mathrm{cal} / \mathrm{g} /$ spec./30 days $)$ & $31.76 \pm 14.45$ & $4.99 \pm 1.15$ & $21.71 \pm 21.03$ & $1.35 \pm 1.35$ & $177.96 \pm 0.63$ & $148.88 \pm 1.90$ \\
\hline $\mathrm{RCV}_{\mathrm{af}}(\mathrm{cal} / \mathrm{spec} . / 30$ days $)$ & $5.27 \pm 2.40$ & $1.84 \pm 0.42$ & $3.17 \pm 3.07$ & $0.51 \pm 0.51$ & $290.82 \pm 1.02$ & $477.28 \pm 6.10$ \\
\hline $\mathrm{E}_{\mathrm{fb}}(\mathrm{J} /$ spec./day $)$ & $0.73 \pm 0.33$ & $0.26 \pm 0.06$ & $0.44 \pm 0.43$ & $0.07 \pm 0.07$ & $40.59 \pm 0.14$ & $66.61 \pm 0.85$ \\
\hline
\end{tabular}

$1 \uparrow$ There were three replicates for each type of food. There were 20 males and females in each group with two replicates (for a total of

2240 individuals). 